\title{
Experiences of final year nursing students in their preparedness to become registered
} nurses

\author{
S Carlson, D Cur \\ Senior Lecturer, Nursing Science, Nelson Mandela Metropolitan University \\ W J Kotzé, D Cur \\ Professor, Nursing Science, Nelson Mandela Metropolitan University \\ D van Rooyen, D Cur \\ Head of Department, Nursing Science, Nelson Mandela Metropolitan University
}

\section{Keywords:}

Student nurse, novice professional nurse, preparedness, lack of confidence, clinical learning environment

\section{Correspondence address:}

Dr Sheree Carlson

Nursing Science Department

Nelson Mandela Metropolitan University

POBox 77000

Pon Elizabeth 6031

\section{Abstract: Curationis 28(4): 65-73}

The objectives of this study were: firstly, to explore and describe the experiences of final year nursing students relating to how they experience their preparedness to fulfil the role of professional nurse; secondly, to explore and describe the experiences of novice professional nurses in the role of professional nurse; finally, to generate a model which will assist the final year nursing student to become a professional nurse. A theory-generative, qualitative, explorative, descriptive and contextual research design was utilized to reach the objectives of the study. Results indicated that final year nursing students experience a lack of confidence to take on the responsibilities of professional nursing. The results are displayed in table form and discussed in the article. This abstract forms part of a bigger study that addresses the professional maturity of the novice professional nurse for the practice of nursing.

\section{Opsomming}

Die doelstellings van hierdie studie was: eerstens, om die ervaringe van finale jaar verpleegstudente ten opsigte van hul gereedheid om die rol van ' $n$ professionele verpleegkundige te vervul, te eksploreer en beskryf; tweedens, om die ervaringe van die nuweling professionele verpleegkundiges in die rol van professionele verpleegkundige te eksploreer en beskryf; laastens, om ' $n$ model te genereer wat tot hulp sal wees vir die finale jaar verpleegstudent om 'n professionele verpleegkundige te word. ' $n$ Teoriegenererende, kwalitatiewe, eksplorerende, beskrywende en kontekstuele navorsingsontwerp was gebruik om die doelstellings van die studie te bereik. Die resultate het aangedui dat die finale jaar verpleegstudente ' $n$ gebrek aan vertroue ten opsigte van die aanvaarding van die verantwoordelikhede van professionele verpleging, ervaar. Die resultate is in ' $n$ tabelvorm weergegee en word in die artikel bespreek. Die abstrak vorm deel van "n groter studie wat die professionele maturiteit van die nuweling verpleegkundige vir die praktyk van verpleging aanspreek.

\section{Sleutelwoorde}

Studentverpleegkundige, nuweling professionele verpleegkundige, gereedheid, gebrek aan vertroue, kliniese leeromgewing 


\section{Introduction}

Graduating as a professional nurse is a special and unique event in the life of an individual who has for the past four years practised in the role of student nurse. The transition phase from student nurse to professional nurse is an exciting one, but it is also a phase hampered by certain anxieties. These anxieties could be sparked by feelings of insufficient knowledge that the student nurse may be experiencing, the fear of making mistakes or of not being able to maintain and assert herself/himself in the health care team as a professional nurse.

As a student, the individual is expected to submit to professional socialization to be able to internalise the values, attitudes and ethics of the nursing profession (Mashaba and Brink, 1994:310). Novice professional nurses may be expected by seniors to perform activities in which they are still inexperienced. They may not always be competent or confident in all areas of their new role. They are expected to be accountable for their actions with regard to nursing care, and participate in prescribed learning situations to meet their programme outcomes. In the new role of an employee the novice professional nurse now needs to conform to the conditions of service of the employing authority. Throughout the basic programme, students are taught to develop skills and are evaluated on the ability to implement these competently in a patient situation. However, the researcher, in her accompaniment of final year nursing students, has heard verbalizations such as "I don't know' where to start with management of a nard..." Mellish, Brink and Paton (1998:4) state that management is, perhaps, one of the least thought about, talked about and understood facets of nursing, but one that co-determines the quality of care.

The novice professional nurse will have to fulfil the management role as a major part of her workload in the clinical environment by ensuring that health care, and not only nursing care, is given. As a professional nurse she is responsible for coordinating services and care. Furthermore, she coordinates care given by the multi-disciplinary team and uses her own initiative when deciding to consult with members of this team.

\section{Problem statement}

Final year nursing students have verbalized to the researcher that they feel "very nervous about starting out as a professional nurse" and that they "do not know if they will be able to cope" with this new role. The following quote reflects the experience of uncertainty of these students in their anticipation of assuming the role of professional nurse:

"I cannot ask the sister/Professional Registered nurse anymore, because I am the sister/Registered/Professional nurse in the ward. I will have a lot of responsibilities and it is very scary".

Pilhammar Andersson (1995:131), in her study of marginality, states that clinical practice within nursing education is described by many nurses as a period in which they "stand with both feet in different boots". This implies that the student nurse's position is at the intersection of two relatively different cultures or traditions, ie academic versus professional. It can be said that the novice professional nurse experiences a "culture shock". There is a separation from a previous identity, namely that of student status, without subsequently being accepted by a new group, namely that of professional nurse. As the student qualifies as a professional nurse, she/he may experience a feeling of "homelessness" and the loss of status as a former student, at the same time adjusting to the role of professional nurse with a load of responsibilities (compare Pilhammar Andersson, ibid).

The anxieties that the final year nursing student experiences are further aggravated by the changing context of clinical learning environments that affects nursing education and practice. The researcher accompanies nursing students in the clinical learning environment and has been made aware of the rapid changes in the clinical learning environment of health care institutions. This has been verbalized by students who state that they are "finding it difficult to adapt to the changing circumstances" of health care institutions.

The focus on community-based education in South Africa has resulted in a shift away from the mainly curatively and institutionally based nurse. Consequently, the emphasis is towards a more preventive, promotive and homebased health care approach. This approach requires students to fulfil practical hours in a community-based setting, which complicates and significantly alters the opportunities for developing institutional management skills. Students have verbalized this to the researcher on re-entering the clinical field after exposure to the community setting, especially before preparing for practical examinations.

The above-mentioned experiences result in qualified professional nurses seeking employment elsewhere. It is a known phenomenon that South African nurses are migrating globally. There is also the implication of a heavier workload and greater responsibilities for the nursing personnel who remain behind and who are expected to competently and with dedication maintain a ward/unit, while simultaneously rendering nursing care of a high quality to patients. This is the type of situation that the novice professional nurse in South Africa currently encounters after graduation.

\section{Research objectives}

The objectives of the study were to:

- $\quad$ Explore and describe the experiences of final year nursing students relating to how they experience their preparedness to fulfil the role of professional nurse.

- Explore and describe the experiences of novice professional nurses in the role of professional nurse.

\section{Definition of terminology}

\section{Registered/Professional nurse}

An individual authorized and capable of practising nursing or midwifery independently by virtue of registration in terms of section 16 of the Nursing Act, 1978 (Act 50 of 1978). Such a person is accountable for prescribing, supervising and carrying out of the nursing regime, coordinating and integrating the multi disciplinary therapeutic regime based on diagnosing the needs and demands of a unique patient in a unique situation, establishing and managing a safe and adequate environment for patient care, assessing patient care situations based on scientific principles and skills, making nursing diagnoses and taking responsibility for her actions (SANC Terminology List, 1994:5 and Kotzé, 1998:10).

\section{Student}

For the purpose of this study, an 
individual who is in the completion phase of a basic four year nursing programme, approved by the South African Nursing Council, so as to meet the minimum requirements for registration as a professional/registered nurse and midwife.

\section{Clinical learning environment}

The clinical learning environment is the environment in which the student is systematically exposed to learning and practice opportunities in real patient and service provider situations. It is a selected environment that will provide physical, psychological, spiritual and social support (utilizing a holistic approach) to patients in order to promote and maintain safe, effective patient care and ensure that programme objectives are met (researcher's definition based on reviewed literature).

\section{Research design and method}

\section{Research Design}

This research study was a theorygenerative, qualitative, explorative, descriptive and contextual design.

\section{Research Method}

The collection of data and the analysis of data were implemented and divided into two phases.

Phase 1 involved the exploring and describing of experiences of final year nursing students and their preparedness to take on the responsibilities of professional nursing. Phase 1 also included the collection of events in the form of narratives from novice professional nurses of events related to their confidence in the role of professional nurse.

Phase 2 followed the interpretation of the data and involved the development of a self-management model towards professional maturity for the practice of nursing.

\section{Method of Data Collection \\ Sampling}

Purposive sampling was used to recruit participants. Purposive sampling is based on the assumption that a researcher's knowledge about the population can be used to handpick the cases to be included in the sample (Polit and Hungler, 1999:229). A sample of ten nursing students was drawn. The sample size was dependent upon saturation of data following the interviews and coding of data.

\section{Sample population}

The population in this study comprised, firstly, the final year nursing students and, secondly, novice professional nurses. All final year nursing students (including a few of those who took part in the interviewing phase) voluntarily submitted their contact details to the researcher on completion of their fouryear programme. They were followed up by the researcher after three months of practising as a registered nurse, briefed as to what was required of them relating to the narrative writing and given a maximum of two weeks within which to post the narratives back. Dufault (1990:74) states that there is now abundant international evidence that the first three months of employment as a professional nurse is crucial in determining her/his acquisition of clinical, technical and patient management skills. Sampling criteria -

The sample population selection criteria were as follows:

\section{Group 1:}

- Final year nursing students who must:

- Be English or Afrikaans speaking to avoid loss of information during the process of interpreting interviews.

- $\quad$ Be in the process of fulfilling programme requirements within the minimum programme duration of four years. (Students who are extending the programme will not be interviewed).

- $\quad$ Be in the process of completing the nursing programme for registration with the South African Nursing Council.

- Represent different cultural groups.

- $\quad$ Represent different gender groups (ie male and female final year students).

- Be doing practicals for the programme in health care environments within the Nelson Mandela Metropole (ie state or private health care providers).

Group 2:

Novice professional nurses who must:

Have completed the programme within the minimum period of four years of study.

Have fulfilled clinical learning requirements in the health care environments within the Nelson Mandela Metropole (ie state or private health care providers). Have been in their present working situation for at least three months post graduation. Have completed the nursing programme and have obtained registration with the South African Nursing Council.

- Represent different cultural groups.

Represent different gender groups (ie male and female novice professional nurses).

Firstly, data was collected from ten final year nursing students by interviewing them, utilizing an unstructured interview technique, and by directly observing them in the clinical field in the role of student. The final year nursing students were asked the following "Tell me how prepared you regard yourself to be to take up the responsibilities of professional nursing".

Secondly, novice professional nurses were contacted telephonically as well as per written letter and asked to describe experiences related to an event where they felt they lacked confidence and an event where they felt they had confidence to deal with a situation in the area where they were practising (as novice professional nurses). Novice professional nurses were given a framework against which they could write their narratives. Written narratives were retumed to the researcher. (Exemplars of the narratives are available on request from the researcheras well as the framework). A total return sample of $68 \%$ of written events was received from the novice professional nurses.

\section{Data analysis}

Interviews were transcribed verbatim and analysed for emergence of themes that were prevalent amongst the participants who were interviewed. The researcher reduced the data meaningfully until the central storyline, as told by the final year nursing student, emerged clearly. Data was analysed according to the descriptive analysis method by Tesch (in Creswell, 1994:155) and themes were formulated. In the process of analysing the data, all copies of interviews and field notes were kept and reviewed for any 


\begin{tabular}{|c|c|c|}
\hline Theme & Sub-themes & Categories \\
\hline $\begin{array}{l}\text { 1. Final year nursing } \\
\text { students experienced a } \\
\text { lack of confidence to } \\
\text { take on the respons- } \\
\text { ibilities of professional } \\
\text { nursing }\end{array}$ & $\begin{array}{l}\text { 1.1 Students related } \\
\text { experiences that negatively } \\
\text { influenced their confidence: } \\
1.1 .1 \text { Students experience } \\
\text { themselves as not being } \\
\text { regarded as emerging } \\
\text { professionals by members of } \\
\text { the multi-disciplinary health } \\
\text { team } \\
\text { l.1.2. Students experienced a } \\
\text { lack of professional nurse role- } \\
\text { models in their professional } \\
\text { socialization }\end{array}$ & $\begin{array}{l}\text { Students experience: } \\
\text { 1.1.1.1 Personnel as inaccessible and antagonistic towards them } \\
\text { when initially placed in the ward. } \\
\text { 1.1.1.2 That they are regarded as workforce in the units. } \\
\text { 1.1.1.3 Themselves as being deprived of the responsibility and the } \\
\text { opportunity to make decisions and use initiative. } \\
\text { 1.1.1.4 Themselves as deprived of the opportunity to ask questions } \\
\text { and verbalize uncertainties about the contlicting manner in which } \\
\text { things are done in the wards compared to what they were taught at } \\
\text { the nursing school. } \\
\text { 1.1.1.5 Ward personnel as disregarding students' knowledge and } \\
\text { experience in the clinical environment. } \\
\text { Students experience: } \\
\text { 1.1.2.1 A lack of work ethic in nursing personnel. } \\
\text { 1.1.2.2 Nursing personnel displaying an uncaring and unempathetic } \\
\text { attitude toward the patients. } \\
\text { 1.1.2.3 A lack of commitment in professional nurses to accompany } \\
\text { students in the wards. } \\
\text { 1.1.2.4 Feedback from nursing personnel on students' performance } \\
\text { as mostly negative. } \\
\text { 1.1.2.5 A lack of professional pride in nursing personnel. }\end{array}$ \\
\hline & $\begin{array}{l}\text { 1.2 Students experienced } \\
\text { certain emotions related to their } \\
\text { lack of confidence } \\
\text { 1.3 Students experienced a need } \\
\text { for structured, direct learning } \\
\text { opportunities to build their } \\
\text { confidence }\end{array}$ & $\begin{array}{l}\text { Students experienced: } \\
\text { 1.2.1 Frustration when they were, due to lack of confidence, unable } \\
\text { to confront the ward staff about poor patient care and other factors } \\
\text { that were troubling them as students. } \\
\text { 1.2.2 Despondence because they perceive themselves as wasting } \\
\text { the professional nurse's time. } \\
\text { 1.2.3 Feelings of inferiority because the ward staff treated them as } \\
\text { if they were ignorant and they did not consider themselves as } \\
\text { members of the multi-disciplinary team. } \\
\text { 1.2.4 Powerlessness because of lack of practice learning } \\
\text { opportunities in the management of health care units. } \\
\text { 1.2.5 Fear of the unknow'n ie of the professional role that will be } \\
\text { expected of them. } \\
\text { 1.2.6 Gratitude and appreciation for the competencies gained } \\
\text { through the programme and the ability to learn to improvise and be } \\
\text { creative with the limited resources at their disposal. } \\
\text { Students experienced the need: } \\
\text { 1.3.1 To be exposed to learning opportunities that would facilitate } \\
\text { management competence. } \\
\text { 1.3.2 For a period of working in a management capacity under the } \\
\text { supervision of the professional nurse. } \\
\text { 1.3.3 For guided reflection to enhance their becoming professional } \\
\text { nurses. }\end{array}$ \\
\hline
\end{tabular}


additional themes related to the findings of the interviews. A copy of the analysis techniques, described by Tesch (in Creswell, 1994:155), the transcribed interviews and the field notes were handed over to an independent coder experienced in the field of research. A meeting between the researcher and the independent coder took place to discuss any recurring themes and to reach consensus regarding the central story line and themes.

Narratives were analysed using a content analysis technique prescribed by Flanagan (1954:3444) as novice professional nurses were requested to write about specific events relating to their confidence to practise as a Registered Nurse.

\section{Literature control}

The literature control verified and recontextualized the identified themes within the existing literature. On completion of the data analysis a literature control was implemented to compare findings from data with existing data in literature (De Vos, 1998:19). This process was implemented with the data collected through interviews with final year nursing students, as well as the data collected from novice professional nurses through the narratives.

\section{Trustworthiness of the study}

In order to ensure trustworthiness of the study, Guba's model in Krefting (1991:215) was utilized. Guba identifies four criteria for trustworthiness. The criteria for trustworthiness were:

Truth Value. This asks how confident the researcher is with the truth of the findings based on the research design, informants and context. The strategy for establishing truth value was credibility (compare Krefting 1991:216). The researcher ensured that those participating in the research were identified and described accurately. The actions to improve credibility were: reflexivity, triangulation and member checking. Reflexivity ensured that extreme over-involvement did not occur between the student and the researcher. The researcher made use of a field journal that reflected her thoughts, feelings and ideas after contact with respondents. In this manner the researcher became aware of biases and preconceived assumptions

Applicability. Applicability refers to the degree to which the findings can be applied (fitted) to other contexts and settings or with other groups (Krefting, 1991:216). The criterion against which applicability was assessed was fittingness or transferability. The researcher determined whether the content of the interviews, the written events and observed events were typical or atypical of the lives of the informants. This was identifiable, as the researcher herself has practised as a professional nurse.

Consistency. Consistency of data refers to whether the findings would be consistent if the enquiry were replicated with the same subjects or in similar context. This is based on the criterion of dependability (Krefting, 1991:216). The researcher utilized a code-recode procedure on the data collected during the analysis phase of the study (on completion of coding a segment of data). After a week the researcher returned to the data, recoded the same data and compared the results. The researcher also consulted with colleagues who are methodological experts, ie peer assessment to check the research plan and implementation thereof. This increased the dependability of the study.

Neutrality. This refers to the degree to which the findings are a function solely of the informants and the conditions of the research and not of other biases, motivations and perspectives. Confirmability is the criterion against which neutrality can be measured (Krefting, 1991:216). Confirmability was established by triangulation of data sources. The researcher provided documentation of each claim or interpretation to ensure that the data supported her analysis and interpretation of the findings.

\section{Ethical considerations}

The researcher considered ethical issues throughout the study. Participants were informed that, if they had any ethical problems concerning the study, they could contact a lecturer who is a representative of the ethics committee at the Nelson Mandela Metropolitan University. The principles implemented to protect the participants in the research study from harm or risk were: the right to protection from discomfort and harm based on the ethical principle of beneficence which states that one should do good and, above all, do no harm, informed consent, confidentiality, anonymity and privacy (Burns and Grove, 1999:166). The participants were informed that they may withdraw from the study at any time. Permission was obtained from the heads of the nursing schools and health care institutions where professional nurses were employed. Students and novice professional nurses were informed of the purpose of the study and were given the opportunity to consent or decline participation in the study. All participants were assured that no information given by them would be shared with another person without their authorization.

\section{Identified themes/results of the study relating to final year nursing students}

The identified central theme and subthemes relating to the experiences of preparedness of final year nursing students are discussed in table 2 .

\section{Discussion of the central theme and sub-themes}

\section{Central theme: Final year nursing students experienced a lack of confidence to take on the responsibilities of professional nursing}

Students verbalized that "although the programme is comprehensive and indepth" they "have no confidence...like I haven't had the chance to sort of...practise things and feel confident about it...once you have confidence to solve a problem, you can solve another problem and the next problem...you build up the confidence to get over the hurdles...you can then get into anything..." lipinge and Malan (2000:51) indicate that, when students have an opportunity to practice what they have learnt, there is strengthening of their abilities resulting in self-confidence and a feeling of self-fulfilment. Students need to develop courage to become competent in nursing practice in order to enhance their confidence; they need to feel safe to do this, to be given the opportunity for practice and they need to receive recognition of status as final year students. However, these opportunities are lacking as evidenced by the following sub-theme 


\section{SUB-THEME: Students related experiences that negatively influence their confidence}

The experiences which negatively influenced the students' confidence are that they:

\section{Experienced themselves as not being regarded as emerging professionals by members of the multi-disciplinary health care team.}

Novice professional nurses are expected to be competent in problem-solving, administration and management activities, applying clinical judgment, researching patient case studies, teaching both the patient and fellow nurses, promoting good interpersonal relationships, caring, applying ethical principles and to portray competence in psychomotor skills. A student confirmed this by saying they should work more closely with members of the health care team. especially the medical practitioners, and they should "be encouraged to stick to the doctor like glue".

Balfour (1987:25) states that theories of nurse education expect students to be self-motivated, research-oriented and prepared to utilize their knowledge in an adventurous manner. Yet, in practice, they are still taught to be safe, obedient and quiet. Factors contributing towards experiences of students not being regarded as emerging professionals by members of the multi-disciplinary team are the following:

Experienced personnel as antagonistic and inaccessible toward them when initially placed in the ward The students experienced the presence of a gap between the professional nurse and themselves and it made them feel uncomfortable, especially "if she is not one that offers to ever help us, especially if I go to herfor advice...I mean... I don't want to make mistakes and I have to ask for help....". Students experienced themselves as being "non-existent" and they verbalized that "no-one would notice if they were not present in the ward". Students doubted their role as student nurse and felt that it was an unimportant role.

Experienced themselves as workforce in the units because they were only allowed to perform basic duties in the ward, observe and continuously run errands
A concept that emerged from the interviews was that the students experienced themselves as workforce because they performed only basic duties in the ward, observed and continuously ran errands. Ashworth and Morrison (1989), Palmer (1994) and Shield (in Nolan, 1998:623) posit that learning only occurs if experiences are used productively. They state that, unfortunately, many studies on student learning in clinical placement show that time is not used effectively. Students said when they are in the wards they are expected to do "everything. We have to go to the dispensary, sometimes three times a day, take patients to X-rays and to scans. I have even driven in the ambulance to other hospitals to take patients...but even in the wards...w'e just make up beds the nhole time and do basic things".

Experienced themselves as being deprived of the responsibility and the opportunity to make decisions and use initiative

A further contributing factor towards the students' lack of confidence is that they experienced themselves as being given neither the responsibility nor the opportunity to think critically and make their own decisions (under supervision of the professional nurse). This is because the student is merely seen as workforce and not as having supernumerary status. The students stated that they would like to be given the opportunity to "take charge and to take the reins". Jolley (1987:30) states that the practice of nursing must excite the student's imagination and enthusiasm. It must provide interest, intellectual stimulation and independent practice for these new experts and it can only be done by focusing on problemsolving and decision-making.

Experienced themselves as deprived of the opportunity to ask questions and verbalize uncertainties about the conflicting manner in which things are done in the wards

The manner in which the student is taught at the nursing school conflicts with the manner in which nursing actions are implemented in the wards. This compounds the student's experiences of feeling unprepared for the role of professional nurse. Although students experienced themselves as competent in performing nursing skills, they mentioned that it is difficult for them to "keep remembering" the way they were taught, especially when doing dressings, because the staff nurses do dressings differently.

Reutter, Field, Campbell and Day (1997:150) acknowledge that nursing students are intensely aware of the discrepancies between what they experience in hospital practice and what they are taught in schools of nursing. Melia (1987:165) found that students coped with this discrepancy through rationalization and compartmentalization. She states that compartmentalization happens when nursing students, in moving from the world of academic education to that of hospital clinical practice, come to terms with two versions of nursing, each with its own standards and rules. Instead of questioning or confronting these diverse philosophies, students coped by rationalizing that they are just passing through and apparently cope by fitting in with each philosophy.

Experienced ward personnel as disregarding their knowledge and experience in the clinical environment Although the students were in their fourth year of study they were not asked to manage bigger responsibilities, for example administering of medication to patients. This is evident in the following quote by a student: "For one, giving out of medicines. It always seems the sister or staff nurse's job. They just call us and we have to take the tablets to the patient. I stand and make sure he swallow's them...but staff nurses just leave them on lockers...and w'e cannot say anything". Students experienced restriction in some routines because the more senior personnel preferred to continue with the work and they were not given responsibility. Responsibility denotes an obligation to accomplish a task and accountability is accepting ownership for the results of or lack thereof (Sullivan and Decker, 1997:67). Fetters Andersen $(1999: 770)$ states that accountability is a process that needs to be nurtured throughout the nursing education experience. A second experience of students that negatively influenced their confidence was the lack of professional nurse role models to socialize them into the profession of nursing.

\section{Experienced a lack of professional nurse role-models in their professional socialization}

From the interviews it was clear that students experienced a lack of 
professional role models to aid in socializing them into the profession of nursing, and that they knew who was and who was not a role-model. Toohey (2002:529) believes that students will pick up certain qualities by being around professionals in their clinical or workplace attachments. She states that the effect of working with positive rolemodels can be significant and that it is, therefore, imperative that students have role-models from whom to learn desirable, professional nursing practice. Very few students could truthfully say that they have had a role-model to whom they could look up to. They knew how they would perform as a professional nurse rolemodel as evidenced by the following quote:" I've seen how I would like to act and how I hope I will never act from different sisters...". Factors contributing towards the experience of a lack of professional nurse role-models were:

Students experienced a lack of work ethic in nursing personnel

Students stated that there were times in the day when no professional nurse was available and they were left on their own. They felt that they were being taken advantage of "because then once the staff come on duty, and they see $O K$ there is two or three students then they think there's more than enough, then they go home, disappear out of the ward, or they take hours off, then they leave...".

Students experienced nursing personnel displaying an uncaring and unempathetic attitude toward the patients

Caring is the goal of therapeutic communication and an attitude that enhances communication. It is the level of emotional involvement between the nurse and the patient and is the foundation of a nurse-patient relationship. It is a relationship in which the nurse uses her therapeutic skills such as genuineness, warmth, empathy, active listening, respect and acceptance of the patient to provide nursing care that will enhance his/her recovery. The uncaring and unempathetic attitude displayed by nursing personnel towards the patients was a concern of all students participating in the interviews. Most students had this to say: "I want to ensure that I give the best nursing care to my patients, and I will ensure that they receive the best they can from me, and that I can do my duties to the best I can, at that moment...that is what I want to be."
Students experienced a lack of commitment in professional nurses to accompany them in the wards

Feelings of inferiority came to the fore and students indicated that they did not deserve to be treated in this manner because they were students. "I am supposed to learn to become a professional nurse and sometimes I wonder why I am in this course. I am supposed to be taking responsibility next year and yet I still feel like...um...like inferior...most of the staff are uninterested in students, and don't care if we do the right thing or not".

Students experienced feedback on their performance as mostly negative The students verbalized that they would appreciate being given the responsibility of performing minor tasks of the professional nurse in their final year, which would aid in developing their confidence. A student stated "I don't expect them to hand over all the responsibility to a student nurse... it is a bit of a touchy situation...but just knowing that you have done something right... If they could come to us and say "well done, I saw you do that" or "we had a good day today, things went well"...that would help a lot too". Students experienced that if they did receive feedback, staff would always begin with the negative feedback and give very little positive feedback (students mentioned that this was also applicable to some lecturers).

Students experienced a lack of professional pride in nursing personnel Students verbalized that professional nurses "take time out" and left them alone to continue with routine work of the unit. They believed that this was because of personnel shortages resulting in time constraints because remaining personnel in the unit have to ensure that daily routines are implemented. This, however, added an extra workload to the remaining team left in the units to complete routines.

\section{SUB-THEME: Students experienced emotions related to their lack of confidence}

The realization by the students that within four months they would be professional nurses brought about varying degrees of emotions. A few students mentioned that they experienced a "reality shock in theirfirst year of practice and it is almost as if the experience will be repeated again when they are "new" professional nurses". Emotions experienced were related to those feelings of frustration, despondence, and feelings of inferiority, fear of the unknown, powerlessness, as well as gratitude and appreciation.

\section{SUB-THEME: Students experienced a need for structured, direct learning opportunities to build their confidence}

Specific needs are required to successfully fulfil the role of professional nurse.

Students experienced the need to be exposed to learning opportunities that would facilitate management competence During the interviews students mentioned that they did not feel comfortable with, and lacked, leadership skills, delegation skills, coping with conflict in the ward, confrontation skills, the ability to exercise authority, assertiveness skills and supervisory skills.

They stated that most of the management aspects related to nursing practice had been covered in theory alone and no opportunity had been given/made available for them to practise "hands on" and "take control".

\section{Students expressed the need for a period of working in a management capacity under the supervision of the professional nurses}

It was evident from the interviews that the students felt enriched and empowered with a vast amount of theoretical knowledge from the programme. They also felt confident in implementing practical skills. Three students in the interviews had been given the opportunity to "act" as a professional nurse for a month and yet they expressed "it is not enough time, even for a month, to learn about all that goes on in a ward, especially if you haven't been given a chance to be independent in the ward". Mellish (1985:89) states that by organization the professional nurse in charge oils the wheels of the work in the area and keeps them running smoothly. In order to assist in the adaptation from student to professional nurse, the student needs to be given the opportunity to practice this role under the supervision of an experienced 
professional nurse.

The students perceived the need for guided reflection to enhance their becoming professional nurses

Jenkinson ( 1997:60) states that reflection brings self into view. Reflection focuses on personal experience and practice, drawing on many forms of knowledge. This need is verbalized by a student saying "... in class we like to talk about the day, what we have experienced in the practical field and it really helps, especially as far as emotions are concerned, if we can just talk about it. ...but we don't always have the time for this...." Students said that reflection is not encouraged enough and that if they could get the opportunity to speak for fifteen to twenty minutes about the previous day's practicals and discuss this amongst each other it would be extremely meaningful for them, especially hearing what their colleagues had experienced.

\section{Identified themes/results of the study relating to novice professional nurses}

The events derived from the written narratives of novice professional nurses are depicted as follows:

Events described by novice professional nurses which caused them to experience lack of confidence were lack of experience resulting in novice professional nurses feeling vulnerable as members of the health care team, lack of confidence to delegate duties in the unit and to manage a unit and lack of confidence when their self-worth was threatened.

Events described by novice professional nurses that assured them of their confidence in performance were praise and receiving positive feedback about their performance, which resulted in the novice professional nurse experiencing feelings of work satisfaction and increasing confidence. Further events assuring confidence were those relating to meeting patient needs successfully and previous exposure to the opportunity to practise skills.

\section{Limitations of the study}

The following limitations of the study were identified:

- The researcher felt that she was not able to collect as many narratives as anticipated as novice professional nurses had chosen employment in many areas of the country and some were working abroad.

- $\quad$ Narratives collected from novice professional nurses were relatively short and not explained in as much detail as was expected. This could be attributed to lack of experience in reflective writing skills.

- $\quad$ Most of the novice professional nurses were working in the operating theatre or in the intensive care unit.

\section{Recommendations}

Recommendations are related to research, nursing education and nursing practice.

\section{Recommended Research}

In the light of the limitations identified and the findings of the study, the following is recommended for future research in this regard:

Further research on how the
process of reflection and
reflective writing would benefit
the student in her nursing
practice.
To identify, through application,
whether the guidelines for
operationalization of the model
are effective, practical and
achievable. The operation-
alization of the model is a
requisite for further study and
confirmation of what was
proposed to assist the student
through self-management to
become an independent,
confident practitioner.

\section{Recommendations Related To Nursing Education}

The model is based on the assumption that the student, through selfmanagement, can grow towards professional maturing and take on the role of being assertive, confident, independent and safe, and a good manager in the unit where she is practising. A module could be incorporated in the course content of the nursing programme to develop reflective thinking and reflective writing skills for nursing students from year one of their programme. Educators must be prepared and trained by appropriate experts to become skilled in reflection themselves and develop an awareness of the process. Recommendations Related To

\section{Nursing Practice}

The following recommendations are proposed:

- Holding workshops to teach and increase awareness of selfmanagement leading to confidence and professional maturing towards nursing practice; these should form part of the annual programme of nursing students and the personnel development programme/in-service education programmes of clinical health care personnel; nursing school personnel should contribute to and assist with these.

- Quality improvement programmes need to be established in clinical learning environments to provide adequately for opportunities where students can develop self-management skills towards confidence on completion of their programme.

\section{Conclusion}

On completion of the nursing programme, the newly qualified nurse is expected to be competent, innovative and independent in decision-making and in taking responsibility in the health care institution where she is employed. Students need to be prepared for this role and for entering into the rank of qualified professional nurse with confidence in the ever changing and increasingly demanding health care environments.

\section{Bibliography}

BALFOUR, D 1987: In a Class of Their Own - the Student Dilemma. Nursing Times, April 8

BURNS, N \& GROVÉ, SK 1999: Understanding Nursing Research. $2^{\text {nd }}$ Edition. USA: Saunders Company

CRESWELL, JW 1994: Research Design: Qualitative and Quantitative Approaches. London: Sage Publications

DE VOS, AS 1998: Research at Grass Roots. Pretoria: Van Schaik

DUFAULT, M. 1990: Personal and Workmilieu resources as Variables Associated 
with Role Mastery in the Novice Nurse. Journal of Continuing Education in Nursing. 21 (2): 73-78

FETTERS ANDERSEN, CA 1999: Nursing Students to Nursing Leader. The Critical Path to Leadership Development. USA: Delmar

FLANAGAN, J 1954: The Critical Incident Technique. Psychological Bulletin. 21: 327-358

IIPINGE, N \& MALAN, E 2000: Experiences of Final Year Diploma Nursing Students in a Per-Urban Placement Programme. Windhoek, Namibia. Africa Journal of Nursing and Midwifery. November

JENKINSON, TP 1997: Adolescents as Reflective Practitioners: Implications for Nurse Education. Nurse Education Todav. 17: 58-61

JOLLEY, J 1987: Too little, too late. Nursing Times. April 8, 28-29

KOTZE, WJ 1998: An Anthropological Nursing Science, Nursing accompaniment theory. Health SA. 3(2): 3-14

KREFTING, L 1991: Rigor in Qualitative Research: the Assessment of Trustworthiness. The American Journal of Occupational Therapv. 45 (3): 214-222

MASHABA, TG \& BRINK, HI 1994: Nursing Education. An International Perspective. Cape Town: Juta

MELIA, K 1987: Learning and working: the Occupational Socialization of Nurses. London: Tavistock

MELI ISH,JM; BRINK, HIL \& PATON. F 1998: Teaching and Learning the Practice of Nursing. $4^{\text {th }}$ Edition. Johannesburg: Heinemann

MELLISH, JM 1985: Administering the Practice of Nursing. Durban: Butterworths

NOLAN, CA 1998: Learning on clinical Placement: the Experiences of Six Australian Student Nurses. Nurse Education Todav, 18: 622-629

PILHAMMAR ANDERSSON, E 1995: Marginality: Concept or Reality in Nursing Education? Journal of Advanced
Nursing. 21: 131-136

POLIT, DF \& HUNGLER, BP 1999: Essentials of Nursing Research, Methods, Appraisal and Utilization. 5th Edition. Philadelphia: JB Lippincott Company

REUTTER, L; FIELD, P; CAMPBELL, I \& DAY, R 1997: Socialization into Nursing: Nursing Students as Learners. Journal of Nursing Education. 36 (4): 149. 155

SOUTH AFRICAN NURSING COUNCIL. Terminology List. 50 years. 1944-1994. Pretoria

SULLIVAN, EJ \& DECKER, PJ 1997: Effective Leadership and Management in Nursing. $4^{\text {th }}$ edition. New York: AddisonWesley

TOOHEY, S 2002: Assessment of Student's Personal Development as Part of Preparation for Professional Work - is it Desirable and is it Feasible? Assessment and Evaluation in Higher Education. 27(6): 529-538

Acts:

SOUTH AFRICA (REPUBLIC) 1978: The Nursing Act (Act 50 of 1978, as amended). Pretoria: Govemment Printers. 